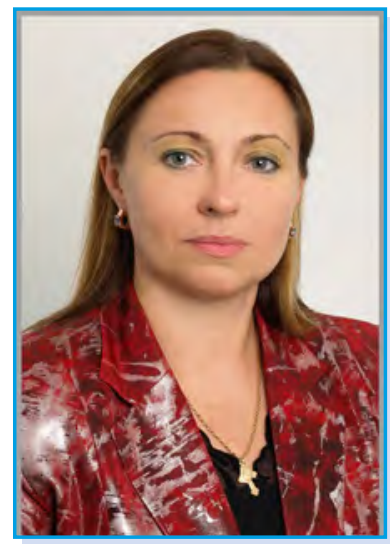

Оксана Васюк - доктор педагогічних наук, професор, професор кафедри педагогіки Національного університету біоресурсів і природокористування України, м. Київ, Україна.

Коло наукових інтересів: педагогіка вищої школи, зокрема формування професійної спрямованості майбутніх фахівців у закладах вищої освіти.

o.vasiuk@nubip.edu.ua

https://orcid.org/0000-0003-0926-7599

аспірант кафедри педагогіки Національного університету біоресурсів і природокористування України, м. Київ, Україна.

Коло наукових інтересів: професійна освіта, зокрема формування проектної компетентності майбутніх менеджерів у процесі професійної підготовки.

golevagoeva31@gmail.com

https://orcid.org/0000-0001-7394-9098

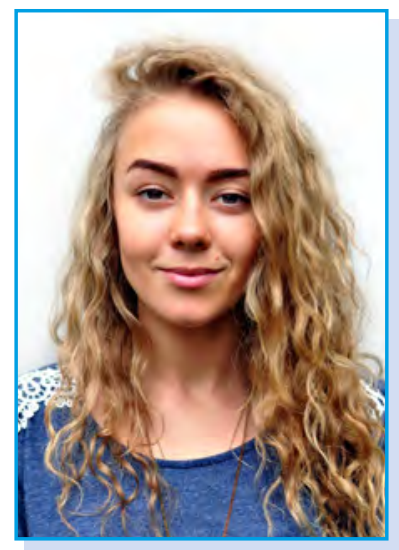

УДК 378.147

https://doi.org/10.32405/2411-1317-2021-4-165-170

\title{
ФОРМУВАННЯ ПРОЕКТНОÏ КОМПЕТЕНТНОСТІ МАЙБУТНІХ МЕНЕДЖЕРІВ ЗА ДОПОМОГОЮ ІНТЕРАКТИВНИХ ФОРМ ТА МЕТОДІВ НАВЧАННЯ
}

У статті наведені проблеми, пов’язані з якістю підготовки майбутніх менеджерів, ідеться про невідповідність вимог роботодавців сучасного ринку праці підготовці випускників. У статті акцентується на тому, що випускник, найперше, повинен бути конкурентоспроможним і готовим до безперервного розвитку. Саме формування проєктної компетентності допомагає випускникам успішно розвиватися в обраній ними професії. Одними з нововведень для формування проєктної компетентності майбутніх менеджерів $€$ такі інтерактивні методи і форми навчання: «проблемнопроектна» лекція, імітаційні методи активного навчання, проєктно-ділова гра, метод проєктів і кейс-метод. У статті описано методичні аспекти названих методів і форм навчання, розкрито їх суть та ефективність застосування у процесі професійної підготовки. Зроблено висновки, що аналізовані інтерактивні методи і форми навчання дозволяють активізувати мислення студентів, спонукають до самостійних рішень, а висока продуктивність навчання можлива лише при комплексному їх застосуванні.

Ключові слова: проєктна компетентність, лекція, проєкт, інтерактивне навчання, проблемнопроєктна лекція, компетентність. 
Постановка проблеми. Сучасні соціальні запити в підготовці кадрів, готових до планування, проєктування, оптимальної організації своєї професійної діяльності обумовлюють появу в професійній компетентності майбутнього менеджера нових складових, в числі яких ми виділяємо проєктну компетентність. Від ступеня сформованості цієї компетентності залежить успішність майбутнього випускника на ринку праці, чи зможе той реалізувати себе повною мірою, що і викликає актуальність розгляду цього питання.

Аналіз останніх досліджень і публікацій. Аспекти формування та розвитку проєктної компетентності найбільш точно розкрито у дослідженнях Т.А. Парфенової. Проєктну компетентність автор визначає як складне інтегративне поняття, з управлінською, емоційно-особистісною, творчою складовими. Проєктна компетентність полягає в здатності розробляти і реалізовувати проєкти (Парфенова, 2018, с. 97). С.Б. Сєрякова зазначає, що будь-яку компетентність можна сформувати та перевірити лише в діяльності (Серякова, 2012, с. 38). А. А. Баранов, Р.Н. Шарафутдинов у своїх роботах розглядають, яка саме діяльність, а також які інтерактивні методи та форми формують проєктну компетентність у майбутніх спеціалістів (Баранов \& Шафарутдинов, 2016). О.В. Касьянов розкриває можливість формування проєктної компетентності під час здобуття професійної освіти за допомогою методу проєктів (Касьянов, 2007).

Формулювання цілей статті. У нашому дослідженні ми дотримуємося думки Т. А. Парфенової про те, що проєктна компетентність $€$ компонентом складної системи професійної компетентності, обумовлена сукупністю певних якостей особистості, ії високим рівнем професійної підготовленості до проектної діяльності (Парфенова, 2018, с. 62). Проєктна компетентність майбутнього менеджера характеризується його здатністю і готовністю застосовувати знання, уміння та особистісні якості, що забезпечать успішність виконання проєктної діяльності, усвідомленням соціальної значущості професії менеджера та особистої відповідальності за результат.

Будь-яка компетентність, як справедливо зазначила професор С.Б. Сєрякова в своїй роботі «Компетентнісний підхід в освіті: від теорії до практики», може бути сформована тільки в діяльності, і перевірити її можна тільки в діяльності (Серякова, 2012, с. 38). Спираючись на таке положення, припускаємо, що проєктна компетентність майбутнього менеджера як складова його професійної компетентності може бути оптимально сформована активною проєктною діяльністю студента в період навчання у закладі вищої освіти. Отже, невід’ємною частиною навчальновиховного процесу, спрямованого на вирішення цієї проблеми, $є$ інтерактивне навчання, здійснюване в різних формах спільної діяльності студентів. При цьому всі суб'єкти освітнього процесу взаємодіють один з одним, спільно вирішують навчальні завдання. Метою цієї роботи є розкрити ефективність застосування різних інтерактивних форм і методів навчання у формуванні проєктної компетентності майбутніх менеджерів.

Виклад основного матеріалу. Упровадження інтерактивних методів і форм навчання в освітній процес сучасного закладу вищої освіти орієнтує педагогів на надання студентам не готової системи навчальної інформації, а створення умов для ініціативності самих студентів, отримання знань шляхом активної діяльності.

У порівнянні з традиційними формами ведення занять, в інтерактивному навчанні змінюється взаємодія викладача і студента: активність педагога поступається місцем активності студентів, а завданням педагога стає створення умов для їх ініціативи.

Під час діалогового навчання студенти вчяться критично мислити, вирішувати складні проблеми на основі аналізу обставин і відповідної інформації, зважувати альтернативні думки, ухвалювати продумані рішення, брати участь у дискусіях, спілкуватися з іншими людьми. Для цього на заняттях організовуються парна і групова робота, застосовуються дослідні проєкти, рольові ігри, йде робота $з$ документами і різними джерелами інформації, використовуються творчі роботи.

Студент стає повноправним учасником навчального процесу, його досвід служить основним джерелом навчального пізнання. Педагог не дає готових знань, але спонукає учасників до самостійного пошуку і виконує функцію помічника в роботі. 
Інтерактивні форми проведення занять:

- пробуджують у студентів інтерес;

- заохочують активну участь кожного в навчальному процесі;

- звертаються до почуттів кожного студента;

- сприяють ефективному засвоєнню навчального матеріалу;

- надають багатоплановий вплив на студентів;

- здійснюють зворотний зв’язок (відповідна реакція аудиторії);

- формують у студентів думки і стосунки;

- формують життєві навички;

- сприяють зміні поведінки.

Концепція інтерактивного навчання передбачає кілька моделей навчання:

1) пасивна - студент виступає в ролі «об'єкта» навчання (слухає й дивиться);

2) активна - студент виступає «суб’єктом» навчання (самостійна робота, творчі завдання, курсові роботи / проєкти тощо);

3) інтерактивна - взаємодія, рівноправне партнерство. Використання інтерактивної моделі навчання передбачає моделювання життєвих ситуацій, використання рольових (ділових) ігор, спільне вирішення проблем.

Виключається домінування будь-якого учасника навчального процесу або будь-якої ідеї. 3 об’єкта впливу студент стає суб’єктом взаємодії, він сам є активним у навчанні, слідує своїм індивідуальним маршрутом.

Усі технології інтерактивного навчання діляться на неімітаційні та імітаційні.

Неімітаційні технології не передбачають побудови моделей досліджуваного явища і діяльності.

В основі імітаційних технологій лежить імітаційне або імітаційно-ігрове моделювання, тобто відтворення в умовах навчання процесів, що відбуваються в реальній системі (Мельничук \& Цибух, 2017, с. 71).

Сучасна педагогіка багата цілим арсеналом інтерактивних підходів, серед яких можна виділити наступні:

- творчі завдання;

- робота в малих групах;

- навчальні ігри (рольові ігри, імітації, ділові ігри);

- використання суспільних ресурсів (запрошення фахівця, екскурсії);

- соціальні проєкти та інші поза аудиторні методи навчання (змагання, інтерв’ю, фільми, вистави, виставки);

- вивчення та закріплення нового матеріалу (інтерактивна лекція, робота з наочними посібниками, відео- і аудіоматеріалами, використання питань);

- тестування;

- розминки;

- зворотний зв'язок;

- дистанційне навчання;

- обговорення складних і дискусійних питань і проблем (займи позицію, шкала думок, ПОПС-формула);

- вирішення проблем («дерево рішень», «мозковий штурм», «аналіз казусів», «сходи і змійки»);

- тренінги.

Надати допомогу в оптимальному засвоєнні навчального матеріалу дозволяє застосування такої форми інтерактивного навчання, як проблемна лекція. Проведення навчальних занять у такій формі дозволяє залучати студента до ситуації, яка вимагає від нього не просто актуалізувати свій життєвий досвід, а й якісно трансформувати його. У порівнянні з традиційними лекціями, проблемні лекції орієнтовані на активність студентів, а завданням педагога стає створення умов для їх ініціативи. 
У рамках нашого дослідження викликає інтерес така інтерактивна форма, як «проблемнопроєктна» лекція, докладний опис якої представлено в роботі А.А. Баранова, Р.Н. Шарафутдинова. Основне завдання «проблемно-проєктної» лекції полягає в інтеграції методичного, предметного і проєктного напрямків. Лекція складається з таких елементів: пізнавальна діяльність, пошук проблем, знаходження ідей, їх розробка і реалізація у вигляді проєктної діяльності, упровадження розробок на практиці. Застосування такої форми інтерактивного навчання в навчальному процесі дозволить залучити студента до інноваційної діяльності і сформувати у нього проєктну компетентність (Баранов \& Шафарутдинов, 2016, с. 104).

А. М. Смолкін виділяє імітаційні методи активного навчання, тобто форми проведення занять, в яких навчально-пізнавальна діяльність побудована на імітації професійної діяльності. Їх мета - надати студентам можливість у творчій обстановці закріпити ті чи інші навички, акцентувати увагу на певному важливому понятті, категорії, законі (імітаційний тренінг, розігрування ролей, ігрове проєктування, дидактична гра). В умови імітаційної вправи повинно міститися обов'язкове протиріччя, елемент проблематики.

Після імітаційних вправ можна переходити до ділових ігор, які мають великий потенціал у формуванні проєктної компетентності майбутніх менеджерів, засновані також на імітації професійної діяльності. Ігрове моделювання, як відзначають В.А. Сластьонін, Л.С. Подимова, має на меті розвиток творчого потенціалу, орієнтоване на пошук самостійного вирішення того чи іншого професійного завдання (Сластенин \& Подимова, 2007, с. 48).

У навчальному процесі - це, швидше, рольова гра, адже студенти ще не уповні володіють своєї спеціальністю. Мета такої гри - сформувати певні навички і вміння через активний творчий процес.

Перевага ділової гри як методу інтерактивного навчання полягає в можливості моделювання стандартних і нестандартних професійно-орієнтованих ситуацій, направлених на активізацію творчого мислення студентів, формування їх аналітичних умінь, розвиток здібностей колективної роботи, розкриття внутрішніх резервів особистості студента. Пріоритетним видом ділової гри, у рамках досліджуваної проблеми, $є$ проєктно-ділова гра, яка спрямована на створення і запуск проєкту, набуття і відпрацювання навичок ефективної групової роботи.

Широкі можливості у формуванні проєктної компетентності майбутніх менеджерів відкриває застосування методу проєктів, який дозволяє студентам оволодіти компетенціями під час роботи над практичними завданнями, що поступово ускладняються - проєктами. Провідною метою навчання за допомогою методу проєктів виступає створення умов, які сприяють формуванню специфічних умінь проєктування, дослідницьких умінь і навичок критичного мислення.

3 позиції студентоцентрованого підходу О.В. Касьянов розкриває метод проєктів як навчання, що створює умови для творчої самореалізації, підвищує мотивацію до навчання, сприяє розвитку інтелектуальних здібностей, відповідальності, самостійності здобувачів вищої освіти, умінню приймати рішення, планувати, оцінювати результати, а найголовніше, здобувачі набувають досвіду розв’язання реальних проблем у майбутній професійній діяльності (Касьянов, 2007).

До цих переваг проєктного навчання А.С. Сиденко додає: формування навичок самостійної орієнтації в джерелах, розвиток основних видів мислення, сприяння психічному розвитку здобувачів вищої освіти; привчання до реальної самоосвіти, формування творчого системного мислення, культури ділового спілкування та посилення уяви (Сиденко, 2003).

Уведення в освітній процес такого інтерактивного методу навчання сприяє оволодінню студентами системою знань про проєктну діяльність, засвоєння її способів, а також застосування отриманих навичок у процесі самостійної проєктної діяльності. Проєктний метод навчання, отже, виступає важливим ресурсом формування проєктної компетентності майбутніх менеджерів і повинен реалізовуватися в усіх видах діяльності студентів.

Кейс-метод (з англійського case - випадок, ситуація) - вдосконалений метод аналізу конкретних ситуацій, метод активного проблемно-ситуаційного аналізу, заснований на навчанні шляхом вирішення конкретних завдань - ситуацій (вирішення кейсів). 
Метод кейсів являє собою вивчення, аналіз і ухвалення рішень відповідно до ситуації (проблеми), яка виникла в результаті подій, що відбулися, або може виникнути за певних обставин. Розрізняють польові ситуації, засновані на реальному фактичному матеріалі, і крісельні (вигадані) ситуації, кейси. Студенти повинні проаналізувати ситуацію, розібратися в суті проблем, запропонувати можливі рішення і вибрати найкраще з них.

Висновки та перспективи подальших досліджень. Розглянуті інтерактивні методи і форми навчання дозволяють активізувати мислення студентів, інтенсифікувати вироблення самостійних рішень; це забезпечить велику продуктивність навчання. У формуванні проєктної компетентності майбутніх менеджерів найбільший ефект дає комплексне застосування таких форм і методів інтерактивного навчання, як «проблемно-проєктна» лекція, проєктно-ділова гра, метод проєктів і кейс-метод.

Експеримент щодо впровадження комплексного застосування вищерозглянутих інтерактивних форм навчання під час здобуття професійної освіти перебуває на концептуальнодіагностичному етапі дисертаційного дослідження на тему «Формування проєктної компетентності майбутній менеджерів у процесі професійної підготовки».

\section{Використані джерела}

[1] Парфёнова, Т. А. (2018). Формирование проектной компетентности будущих педагогов начальной школы: дис. канд. педагог. наук. Самарский государственный социально-педагогический университет. Самара, Россия.

[2] Серякова, С. Б. (2012). Компетентностный подход в образовании: от теории к практике. Совет ректоров. (4). 34-40.

[3] Мельничук, I. В., Цибух, Л. М. (2017). Використання інноваційних методів під час роботи із студентамипсихологами. Science and Education a New Dimension. Pedagogy and Psychology. (V, 58). 71-72.

[4] Баранов, А. А., Шарафутдинов, Р. Н. (2016). Формирование и развитие проектной компетентности как условие становления инновационного потенциала бакалавров педагогического образования и профессионального обучения. Вестник Удмуртского государственного университета. (3). 103-109.

[5] Сластёнин, В. А., Подимова, Л. С. (2007). Готовность педагога к инновационной деятельности. Сuбирский педагогический журнал. (1). 42-49.

[6] Касьянов, О. В. (2007). Проектна технологія у навчально-виховному процесі: посіб. для самостійної роботи слухачів курсів підвищення кваліфікації. Луганськ, Україна.

[7] Сиденко А.С. (2003). Метод проектов: история и практика применения. Завуч для адм. шк. (6). 96-111.

\section{References:}

[1] Parfjonova, T. A. (2018). Formirovanie proektnoj kompetentnosti budushhih pedagogov nachal'noj shkoly: dis. kand. pedagog. nauk. Samarskij gosudarstvennyj social’no-pedagogicheskij universitet. Samara, Rossija. (in Russian).

[2] Serjakova, S. B. (2012). Kompetentnostnyj podhod v obrazovanii: ot teorii k praktike. Sovet rektorov. (4). 34-40. (in Russian).

[3] Mel`ny`chuk, I. V., Cy`bux, L. M. (2017). Vy`kory`stannya innovacijny`x metodiv pid chas roboty` iz studentamy`-psy`xologamy`. Science and Education a New Dimension. Pedagogy and Psychology. (V, 58). 71-72. (in Ukrainian).

[4] Baranov, A. A., Sharafutdinov, R. N. (2016). Formirovanie i razvitie proektnoj kompetentnosti kak uslovie stanovlenija innovacionnogo potenciala bakalavrov pedagogicheskogo obrazovanija i professional'nogo obuchenija. Vestnik Udmurtskogo gosudarstvennogo universiteta. (3). 103-109. (in Russian).

[5] Slastjonin, V. A., Podimova, L. S. (2007). Gotovnost' pedagoga k innovacionnoj dejatel'nosti. Sibirskij pedagogicheskij zhurnal. (1). 42-49. (in Russian).

[6] Kas`yanov, O. V. (2007). Proektna texnologiya u navchal’no-vy`xovnomu procesi: posib. dlya samostijnoyi roboty`sluxachiv kursiv pidvy`shhennya kvalifikaciyi. Lugans`k, Ukrayina. (in Ukrainian).

[7] Sidenko A. S. (2003). Metod proektov: istorija i praktika primenenija. Zavuch dlja adm. shk. (6). 96-111. (in Russian). 
Oksana Vasiuk, D. Sc. (Pedagogy), Professor, Professor of the Department of Pedagogy, National University of Life and Environmental Sciences of Ukraine, Kyiv, Ukraine.

Maria Holieva, postgraduate student of the Department of Pedagogy, National University of Life and Environmental Sciences of Ukraine, Kyiv, Ukraine.

\section{FORMATION OF PROJECT COMPETENCE OF FUTURE MANAGERS IN THE PROCESS OF PROFESSIONAL TRAINING}

The article presents problems related to the quality of training of future managers, i.e., noncompliance with the requirements of employers in the modern labor market of graduate training. Not all existing methods and forms of training contribute to the proper level of project competence formation. The article emphasizes that the graduate, first of all, must be competitive and ready for continuous development. The project competence of the manager is characterized by his ability and willingness to apply knowledge, skills and personal qualities that will ensure the success of project activities, awareness of the social significance of the manager's profession and personal responsibility for the result. Project competence is a component of a complex system of professional competence, due to a set of certain personality traits, its high level of professional readiness for project activities. Thus, an integral part of the educational process aimed at solving this problem is interactive learning, carried out in various forms of joint activities of students. One of the innovations for the competent formation of project competence in the training of future managers is the following interactive methods and forms of learning: "problem-project" lecture, simulation methods of active learning, project-business game, project method and case method. The article describes the methodological aspects of these methods and forms of teaching. It is concluded that the considered interactive methods and forms of learning allow to activate students' thinking, to intensify the development of students' independent decisions that will ensure greater learning productivity. In the formation of project competence of future managers, the greatest effect is the complex application of such forms and methods of interactive learning as "problem-project" lecture, simulation methods of active learning, projectbusiness game, project method and case method.

Keywords: project competence; lecture; project; interactive learning; problem-project lecture; competence. 